\title{
Crop Diversity and Cropping Patterns of Comilla Region
}

\author{
A Saha ${ }^{1 *}$, M Nasim ${ }^{1}$, M Harunur Rashid ${ }^{1}$ and S M Shahidullah ${ }^{1}$
}

\begin{abstract}
Comilla region is highly diverse in respect to topography, agro-ecology, land-use pattern and cropping systems. Planning of agricultural development largely depends on the reliable and comprehensive statistics of the existing cropping patterns, cropping intensity and crop diversity of a particular area, which will provide guideline to our policy makers, researchers, extensionists and development workers. The study was conducted over all 33 upazilas of Comilla region during 2016 using pre-tested semistructured questionnaire with a view to document the existing cropping patterns, cropping intensity and crop diversity. From the present study it was observed that $73.56 \%$ of net cropped area (NCA) is covered by exclusive rice cropping systems whereas deep water rice cropping system occupied $16.09 \%$ of the regional NCA. The most dominant cropping pattern single Boro alone occupied $26.18 \%$ of NCA with its distribution over 30 out of 33 upazilas. The second largest area, 19.93\% of NCA, was covered by Boro-Fallow-T. Aman cropping pattern, which was spread over 25 upazilas. One hundred and forty-six cropping patterns were identified in the whole region under this investigation. The highest, 36 cropping patterns were identified in Debidwar upazila of Comilla district and the lowest, seven were in Akhura and Ashuganj of B.Baria and Comilla Adarsha upazila. The lowest crop diversity index (CDI) was reported 0.481 in Comilla Adrasha upazila followed by 0.637 in Hajiganj of Chandpur. The highest value of CDI was observed 0.964 in Haimchar of Chandpur followed by 0.956 in Muradnagar of Comilla. The range of cropping intensity $(\mathrm{CI})$ value was recorded $126-292 \%$. The maximum value was for Barura of Comilla and minimum for Hajiganj of Chandpur district. The grand mean of CDI values for Comilla region was calculated 0.935 and the average cropping intensity at regional level was $192 \%$.
\end{abstract}

Key words: Cropping pattern, diversity index, Akhaura terrace and Floodplain

\section{INTRODUCTION}

Comilla region comprises 33 upazilas of Comilla, Chandpur and Brahmanbaria districts covering plains, char lands, terrace, basins and Lalmai hills. Comilla is the biggest district with 16 upazilas, located about 100 kilometers south -east of the capital city, Dhaka. The economy is mainly based on agriculture; the economy of Comilla has been flourished through trade and cottage industries, especially the 'Khadi' textile. Brahmanbaria and Chandpur include nine and eight upazilas respectively, also with agriculture based economy; Ashuganj fertilizer factory in Brahmanbaria and Chanpur CIP project are of major importance institutions in agriculture. Major rivers passing through
Comilla region include the Meghna, Gumti, Titas, Little Feni etc. Comilla region is bordered by Habiganj and Kishoreganj districts to the north, Noakhali, Laxmipur and Feni districts to the south, Tripura of India to the east, and Meghna river, Narsingdi, Narayanganj, Munsiganj and Shariatpur districts to the west. The tropic of cancer passes through the heart of the Comilla city; the climate is subtropical biased. Eight agro-ecological zones comprises the whole Comilla region, which are briefly described below (FAO, 1988).

Active Brahmaputra-Jamuna Floodplain (AEZ-7). Parts of Chandpur district belongs to this floodplain, which comprises the belt of unstable alluvial land along the BrahmaputraJamuna rivers where land is constantly being 
formed and eroded by shifting river channels. It has an irregular relief of broad and narrow ridges and depressions. The area is occupied by sandy and silty alluvium, rich in weatherable $\mathrm{K}$ minerals that are slightly alkaline in reaction. Organic matter status is low and fertility status is low to medium.

Middle Meghna River Floodplain (AEZ16). Parts of all the three districts of Comilla, Brahmanbaria and Chandpur districts belong to this flood plain. This floodplain occupies an abandoned channel of the Brahmaputra river on the border between the greater Dhaka and Comilla districts. The region includes areas of old Brahmaputra chars within the Meghna river as well as adjoining parts of the mainland. Soils of the area are grey loam on the ridges and grey to dark grey clays in the basins. The dominant general soil type is non-calcareous grey floodplain soil. Topsoils are strongly acidic and subsoils are slightly acidic to slightly alkaline.

Lower Meghna River Floodplain (AEZ17). Parts of Chandpur district belongs to this floodplain, this area occupies the transitional area between the middle Meghna river floodplain and the young Meghna estuarine floodplain. Soils of this area are relatively uniform, silt loams occupy relatively higher areas and silty clay loams occupy the depressions. Non-calcareous dark grey floodplain and calcareous grey floodplain soils are major components of general soil types. Topsoils are moderately acidic and subsoils neutral in reaction. General fertility level is medium to high with low to medium organic matter status and K-bearing minerals.

Old Meghna Estuarine Floodplain (AEZ19). Parts of all the three districts of Comilla, Brahmanbaria and Chandpur districts belong to this flood plain, which occupies a large area, mainly low-lying land between the south of the Surma-Kushiyara floodplain and the northern edge of the young Meghna estuarine floodplain. Silt loam soils predominate on highlands and silty clay to clay on lowlands. Organic matter content of the soils is moderate. Topsoils are moderately acidic, but subsoils are neutral in reaction. General fertility level is medium with low $\mathrm{N}$ and organic matter.
Sylhet Basin (AEZ-21). Parts of Brahmanbaria district belong to Sylhet Basin which occupies the lower, western side of the Surma-Kushiyara floodplain. Relief is locally irregular near rivers. Soils of the area are grey silty clay loams and clay loam on the higher parts that dry out seasonally and grey clays in the wet basins. The soils have a moderate content of organic matter and soil reaction is mainly acidic. Fertility level is medium to high.

Northern and Eastern Piedmont Plains (AEZ-22). Parts of Brahmanbaria and Comilla belong to this piedmont plain, which is a discontinuous region occurring as a narrow strip of land at the foot of the northern and eastern hills. The region comprises merging alluvial fans which slope gently outward from the foot of the northern and eastern hills into smooth, low-lying basins. Grey piedmont soils and non-calcareous grey floodplain soils are the major general soil types of the area. Soils of the area are loams to clays, slightly acidic to strongly acidic in reaction. General fertility level is low to medium.

Northern and Eastern Hills (AEZ-29). Small part of Comilla district is included in the country's hill areas. Highland comprises 93\% of the total floodplain, relief is complex. Hills have been dissected to different degrees over different rocks. In general, slopes are very steep and few low hills have flat summits. Brown hill soil is the predominant general soil type of the area. Organic matter content and general fertility level are low.

Akhaura Terrace (AEZ-30). The region occupies the eastern border of Brahmanbaria district. The main soils in the uplands have strong brown clay. The valley soils range from silty clay to clays. Deep red brown terrace soils, grey piedmont soils and acid basin clays are the major components of the general soil types of the area. The general fertility including organic matter status is low. The soils are strongly acidic in reaction.

Cropping system is the crop production activity of a farm which includes all cropping patterns grown on the farm resources, other household enterprises and the physical, biological, technological and socioeconomic 
factors or environments. A cropping pattern is the yearly sequence, temporal and spatial arrangement of crops or crops and fallow in a given land area. It is dependent on physical, historical, social, institutional and economic factors as well as government policies (Agrawal and Kassam, 1976). The cropping pattern and the changes therein depend on a large number of factors like climate, soil type, rainfall, agricultural technology, availability of irrigation facilities and other inputs, marketing and transport facilities and growth of agroindustries (Neena, 1998; Gadge, 2003; Rashid et al., 2005).

The yields of cereal crops are tending to stagnation, even in favourable environments. Moreover, cultivable land area is decreasing day by day in the country. In this context, there is no other alternative but to address less favourable and unfavourable environments. To increase the system productivity of the total environment it needs to bring diversity in enterprises for better utilization of limited resources. Detailed information on land situation and cropping systems is a prerequisite for a fruitful development programme. Upazila level office of the Department of Agricultural Extension (DAE) maintains a statistics on individual crop, which has some limitation for getting a real picture of existing cropping patterns and land utilization. The specific objectives of the present study were to:

- Understand the existing cropping pattern scenario in Comilla region

- Visualize the existing land use pattern at upazila and regional level

- Determine the crop diversity and cropping intensity at local and regional level.

\section{METHODOLOGY}

Thirty-three upazilas of Comilla, Brahmanbaria and Chandpur districts under Comilla agricultural region were the locale of this study. Data were collected using double stage procedure. At initial stage, data were collected through pre-tested semi-structured questionnaire from 33 pre-assigned SubAssistant Agriculture Officers (SAAO) of each upazila during November 2015 at upazila level. SAAOs were purposively preselected by Agriculture Extension Officers (AEO), Additional Agriculture Officer (AAO) and Upazila Agriculture Officer (UAO) or altogether. Prior to data collection, the pretested questionnaire was explained along with proper guidelines to the AEOs or UAOs or both and handed over to them at each Deputy Director's office of Directorate of Agricultural Extension (DAE) during monthly meeting for the sake of accurate data collection. The filled questionnaires were collected by the scientists of RFS Division, checked and analyzed to find the inconsistencies of the supplied data before validation workshop. All the inconsistencies among the information were documented. The collected data along with documented inconsistencies were discussed in district level workshop for necessary correction and validation. Second stage of data collection was day-long data validation workshop at district level. The workshop dates were 26 January for Brahmanbaria; 18 February for Chandpur; and 8 May 2016 for Comilla. Four field-workers i.e. one SAPPO and three SAAOs experienced and engaged in crop-based data documentation, all officers from all upazilas viz UAOs, AEOs, AAEOs, DD (DAE), DD (Horticulture), DD of Seed Certification Agency, DTO and ADDs, one representative from Agricultural Training Institute (ATI) and scientists of BRRI regional station, Comilla participated in the data validation workshop. The number of participants of validation workshop ranged from 54 to 111 in each district. All the participants were divided into three to four groups for data validation. Each group was facilitated by two RFSD scientists to finalize and validate the data and authenticated data were captured. Crop diversity index was calculated by using the following equation described by Kshirsagar et al. (1997). 
$C D I_{i}=1-\sum_{j=o}^{n}\left(\frac{a_{i j}}{A_{i}}\right)^{2}$

Where, $\mathrm{CDI}_{\mathrm{i}}=$ Crop Diversity Index

$\mathrm{a}_{\mathrm{ij}}=$ Area planted to the $\mathrm{j}^{\text {th }}$ crop in the $\mathrm{i}^{\text {th }}$ location

$\mathrm{A}_{\mathrm{i}}=$ Total area planted under all crops

The index is zero for a land area growing only one crop. It approaches unity as the level of diversity increases. Compilation and processing of the collected data were done using Microsoft Excel programme. Descriptive statistics were used to facilitate the presentation of the findings.

\section{RESULTS AND DISCUSSION}

\section{Land use pattern}

Table 1 shows upazila-wise land use pattern including net crop area (NCA) and CI. NCA of the whole region is about 4.4 lac hectare with $192 \%$ CI, which is somewhat lower than the national average. Barura upazila of Comilla shows the highest CI of $292 \%$ followed by Debidwar (265\%) and Chandina (250\%) upazilas of the same district which are much more higher than the national average rendering those upazilas as the most intensive cropping area of the country. The highest CI

Table 1. Land use of different upazilas in Comilla region (area in hectare), 2014-15.

\begin{tabular}{|c|c|c|c|c|c|c|c|c|c|c|}
\hline & Upazila & $\begin{array}{l}\text { Area of } \\
\text { upazila }\end{array}$ & $\begin{array}{c}\text { Annual } \\
\text { crop }\end{array}$ & SCA & DCA & TCA & QCA & Other & NCA & C.I. (\%) \\
\hline 01 & Akhaura & 9888 & 20 & 1940 & 4100 & 320 & 0 & 90 & 6470 & 174 \\
\hline 02 & Ashuganj & 6759 & 20 & 300 & 3650 & 1050 & 0 & 80 & 5100 & 215 \\
\hline 03 & B.Baria & 23744 & 10 & 4800 & 8280 & 1820 & 50 & 140 & 15100 & 181 \\
\hline 04 & Bijoynagar & 22007 & 70 & 8500 & 5630 & 350 & 0 & 120 & 14670 & 144 \\
\hline 05 & Bancharampur & 21738 & 20 & 8060 & 5580 & 0 & 0 & 110 & 13770 & 141 \\
\hline 06 & Kasba & 21000 & 110 & 3500 & 8800 & 2830 & 0 & 120 & 15360 & 195 \\
\hline 07 & Nabinagar & 35750 & 20 & 10900 & 12340 & 3000 & 0 & 160 & 26420 & 170 \\
\hline 08 & Nasirnagar & 30262 & 10 & 12260 & 12820 & 870 & 0 & 100 & 26060 & 156 \\
\hline 09 & Sarail & 21527 & 10 & 9500 & 6190 & 680 & 0 & 120 & 16500 & 146 \\
\hline 10 & Chandpur & 30880 & 130 & 4220 & 6900 & 400 & 0 & 80 & 11730 & 166 \\
\hline 11 & Faridganj & 23150 & 200 & 2820 & 8070 & 580 & 40 & 190 & 11900 & 180 \\
\hline 12 & Haimchar & 17400 & 230 & 1040 & 1930 & 1640 & 0 & 140 & 4980 & 208 \\
\hline 13 & Hajiganj & 18991 & 40 & 9000 & 2610 & 250 & 0 & 140 & 12040 & 126 \\
\hline 14 & Kachua & 24725 & 10 & 1300 & 10480 & 4760 & 0 & 150 & 16700 & 221 \\
\hline 15 & Matlab.N & 27760 & 300 & 1120 & 6720 & 6540 & 80 & 120 & 14880 & 236 \\
\hline 16 & Matlab.S & 13175 & 20 & 2900 & 6060 & 10 & 0 & 110 & 9100 & 168 \\
\hline 17 & Shaharasti & 15400 & 15 & 1700 & 7430 & 1300 & 30 & 175 & 10650 & 197 \\
\hline 18 & Barura & 24165 & 170 & 0 & 1460 & 14290 & 450 & 100 & 16470 & 292 \\
\hline 19 & Brahmanpara & 12850 & 10 & 1870 & 3640 & 3870 & 0 & 110 & 9500 & 221 \\
\hline 20 & Burichang & 16376 & 30 & 200 & 5880 & 5300 & 0 & 110 & 11520 & 244 \\
\hline 21 & Chauddagram & 27730 & 30 & 3730 & 12980 & 1610 & 10 & 120 & 18480 & 188 \\
\hline 22 & Chandina & 19804 & 80 & 760 & 4785 & 6205 & 340 & 110 & 12280 & 250 \\
\hline 23 & Com.Adarsha & 12269 & 10 & 5120 & 2130 & 0 & 0 & 100 & 7360 & 129 \\
\hline 24 & Com.South & 24073 & 80 & 600 & 9120 & 6600 & 450 & 130 & 16980 & 240 \\
\hline 25 & Daudkandi & 21021 & 180 & 8200 & 6030 & 230 & 0 & 140 & 14780 & 144 \\
\hline 26 & Debidwar & 23836 & 100 & 525 & 4435 & 10050 & 270 & 120 & 15500 & 265 \\
\hline 27 & Homna & 13279 & 50 & 2500 & 7045 & 210 & 0 & 95 & 9900 & 176 \\
\hline 28 & Nangolkot & 22595 & 20 & 1900 & 7400 & 5160 & 750 & 90 & 15320 & 231 \\
\hline 29 & Laksam & 15652 & 20 & 4310 & 980 & 4780 & 30 & 100 & 10220 & 205 \\
\hline 30 & Meghna & 9455 & 10 & 2100 & 4860 & 0 & 0 & 130 & 7100 & 170 \\
\hline 31 & Monoharganj & 15940 & 30 & 6260 & 3915 & 115 & 0 & 110 & 10430 & 140 \\
\hline 32 & Muradnagar & 34093 & 150 & 2630 & 15870 & 4980 & 0 & 120 & 23750 & 209 \\
\hline \multirow[t]{2}{*}{33} & Titas & 11465 & 10 & 4970 & 2010 & 150 & 0 & 170 & 7310 & 132 \\
\hline & Comilla region & & 2215 & 129535 & 210130 & 89950 & 2500 & 4000 & 438330 & 192 \\
\hline
\end{tabular}


of Barura upazila was resulted from 14,290 ha triple cropped area which is about $87 \%$ of the NCA, at the same time the upazila is lacking single crop area(SCA). Four crop or quadruple crop area (QCA) of more than 300 ha is observed in Nangolkot, Barura, Chandina and Comilla south upazilas of Comilla district. Hajiganj upazila of Chandpur district possesses the lowest cropping intensity of $126 \%$ followed by Comilla Adarsha(129\%) and Titas(132\%) upazilas of Comilla district. Single cropped area (SCA) is the major land use pattern of those upazilas. Area under annual crops is the highest in Matlab South upazila (350 ha) followed by Haimchar (230 ha) and Faridganj (200 ha) upazilas of Chandpur district, while the lowest area (five hectares) under annual crops is found in B. Baria sadar and Sarail upazilas of B.Baria district. For availability of irrigation water, both surface and ground sources in dry season, supply of HYV of various crops, knowledge of modern crop management practices, good communication facilities help increasing land use efficiency in a given area (FAO, 1988).

\section{Cropping patterns of Comilla}

In total 146 cropping patterns is observed in Comilla region of which nine major cropping patterns with exclusive rice crop covers $73.5 \%$ of the NCA, while all 37 cropping patterns with exclusive non-rice crop covers only $8.5 \%$ of the NCA and the rest $18 \%$ of the NCA is covered by 100 rice - non rice cropping patterns (Appendix 1).

\section{Rice and non-rice crops at a glance}

Table 2 presents nine cropping patterns where rice is the only crop round the year. It comprises $73.56 \%$ of the NCA in the region. Among them single rice, double rice and triple areas represent $27.40 \%, 14.78 \%$ and $31.38 \%$ respectively. It reflects the unparallel dominance of rice in the cropping systems in Comilla region. In case of individual pattern single has the highest coverage $(26.18 \%)$ and was recorded in 30 upazilas out of 33. The second dominant pattern Boro-Fallow-T. Aman area occupied 19.93\% of NCA which was distributed in 25 upazilas. Triple rice area for Boro-Aus-T. Aman covered
$14.78 \%$ area with its considerable existence in 26 upazilas.

In the current investigation, 37 cropping patterns were identified that was free from rice. Among these 37 patterns first 23 has been arranged in descending order in Table 3. The rest 14 patterns with negligible area coverage can be found in Table 7 where they are arranged with other patterns of different categories. Aggregate of the 37 patterns have had only $8.51 \%$ of NCA. In critical comparison it is clear that exclusive rice area is about nine folds of exclusive non-rice area. Among these 37 patterns, three patterns comprise yearround vegetables distributed over majority of the upazilas.They had the highest coverage $(3.43 \%)$ which is practiced mainly at or around homestead area.

\section{Deep water rice ecosystem}

Deep water is a special type of ecosystem in the country. In context of Comilla region this ecosystem represents a large portion. The cropping patterns under deep water ecosystem are listed in the Table 4. Among the listed 24 patterns Boro-B.Aman cropping pattern covers the highest area coverage of 38,360 hectares which represents $8.75 \%$ of the region's NCA. This pattern is distributed throughout 19 upazilas out of 33. The second highest MustardB. Aman cropping pattern covers 9,690 hectares and distributed in nine upazilas. The first two patterns jointly covered $10.96 \%$ NCA and this area is about two-thirds of the total area under deep water ecosystem of the region. The water level of this ecosystem ranges between 150 and $400 \mathrm{~cm}$, and water usually remains 3-4 months. Special rice varieties known as 'floating rice' are planted in these areas. In the past Bangladesh had had a land coverage of 3 million hectares for deepwater rice (Jackson et al., 1972). In course of time the continuous effort on modern agriculture shifted DWR area mainly to modern Boro. Now the area under deep water rice in Bangladesh is reduced to 0.4 million hectares (Nasim et al., 2017). Though this cropping system is less productive than the other modern cropping systems, however, the specific fragile ecosystem still struggling because of no other alternatives. 
Table 2. Cropping patterns with exclusive rice in Comilla region, 2014-15.

\begin{tabular}{llrrr}
\hline & Cropping pattern & Area (ha) & \% of NCA & Frequency (no. of upazila) \\
\hline 01 & Boro-Fallow-Fallow & 114780 & 26.18 & 30 \\
02 & Boro-Fallow-T. Aman & 87410 & 19.93 & 25 \\
03 & Boro-Aus-T. Aman & 64830 & 14.78 & 26 \\
04 & Boro-B.Aman & 38360 & 8.75 & 19 \\
05 & Boro-Aus-Fallow & 4670 & 1.06 & 8 \\
06 & Fallow-Aus-T. Aman & 4160 & 0.95 & 4 \\
07 & Fallow-Fallow-T. Aman & 3430 & 0.78 & 1 \\
08 & Boro-Sesbania-T. Aman & 3000 & 0.68 & 2 \\
09 & Boro-Sesbania-Fallow & 1910 & 0.44 & 6 \\
\hline & Total & 322550 & 73.56 & - \\
\hline
\end{tabular}

Table 3. Cropping patterns with exclusive non-rice in Comilla region, 2014-15.

\begin{tabular}{|c|c|c|c|c|}
\hline & Cropping pattern & Area (ha) & $\%$ of NCA & Frequency (no. of upazila) \\
\hline 01 & Potato-Maize-Fallow & 7050 & 1.61 & 5 \\
\hline 02 & Vegetab-Vegetab-Vegetab & 7030 & 1.60 & 22 \\
\hline 03 & Vegetab-Vegetab-Fallow & 6840 & 1.56 & 16 \\
\hline 04 & Potato-Jute-Fallow & 3870 & 0.88 & 11 \\
\hline 05 & Maize-Fallow-Fallow & 1500 & 0.34 & 2 \\
\hline 06 & Vegetab-Fallow-Fallow & 1180 & 0.27 & 6 \\
\hline 07 & S.Potato-Fallow-Fallow & 1060 & 0.24 & 10 \\
\hline 08 & Maize-Vegetab-Fallow & 800 & 0.18 & 1 \\
\hline 09 & Wheat-Jute-Fallow & 780 & 0.18 & 5 \\
\hline 10 & Mustard-Jute-Fallow & 730 & 0.17 & 5 \\
\hline 11 & Chilli-Jute-Fallow & 725 & 0.17 & 6 \\
\hline 12 & Coriander-Fallow-Fallow & 700 & 0.16 & 4 \\
\hline 13 & Soybean-Fallow-Fallow & 700 & 0.16 & 2 \\
\hline 14 & Chilli-Fallow-Fallow & 600 & 0.14 & 3 \\
\hline 15 & Potato-Sesbania & 550 & 0.13 & 2 \\
\hline 16 & Onion-Jute-Fallow & 400 & 0.09 & 2 \\
\hline 17 & Garlic-Jute-Fallow & 390 & 0.09 & 2 \\
\hline 18 & Lentil-Jute-Fallow & 360 & 0.08 & 3 \\
\hline 19 & Fallow-Fallow-Blackgram & 350 & 0.08 & 5 \\
\hline 20 & Vegetab-Jute-Fallow & 335 & 0.08 & 6 \\
\hline 21 & S.Potato-Vegetab-Fallow & 330 & 0.08 & 4 \\
\hline 22 & Chilli-Vegetab-Fallow & 220 & 0.05 & 5 \\
\hline 23 & Lentil-Sesame-Fallow & 170 & 0.04 & 3 \\
\hline \multirow[t]{2}{*}{$24-37$} & Other 14 patterns (in Table 8) & 625 & 0.14 & - \\
\hline & Total & 37295 & 8.51 & \\
\hline
\end{tabular}

\section{Oil-seed crops}

Mustard is the most important one among the oil-seed crops in Comilla region. There are 31 cropping patterns for oil-seed crops among which 14 patterns had been led by mustard alone (Tables 5 and 7). The total share of oil-seed cropping patterns is $6.03 \%$ of NCA whereas Mustard alone occupies over 5\%. The second prevailing soybean covers less than
1\%. The most dominant Mustard-B.Aman pattern is distributed in nine upazilas whereas $2^{\text {nd }}$ dominant Mustard-Boro-Fallow pattern is distributed in 12 upazilas out of 33.

\section{Pulse crops}

Twenty-two cropping patterns are holding different pulse crops (Table 6). Among them lentil is covering the largest area whereas pea is 
Table 4. Cropping patterns under deep-water rice ecosystem in Comilla region, 2014-15.

\begin{tabular}{|c|c|c|c|c|}
\hline & Cropping pattern & Area (ha) & $\%$ of NCA & Frequency (no. of upazila) \\
\hline 01 & Boro-B.Aman & 38360 & 8.75 & 19 \\
\hline 02 & Mustard-B.Aman & 9690 & 2.21 & 9 \\
\hline 03 & Chilli-B.Aman & 3820 & 0.87 & 9 \\
\hline 04 & Potato-B.Aman & 3720 & 0.85 & 8 \\
\hline 05 & Lentil-B.Aman & 2970 & 0.68 & 10 \\
\hline 06 & Vegetab-B.Aman & 2480 & 0.57 & 7 \\
\hline 07 & Wheat-B.Aman & 2140 & 0.49 & 9 \\
\hline 08 & Grasspea-B.Aman & 1785 & 0.41 & 9 \\
\hline 09 & Fallow-Sesame+B.Aman & 950 & 0.22 & 2 \\
\hline 10 & Coriander-B.Aman & 790 & 0.18 & 3 \\
\hline 11 & Soybean-B.Aman & 550 & 0.13 & 1 \\
\hline 12 & Mustard-Boro-B.Aman & 500 & 0.11 & 4 \\
\hline 13 & Mustard-Sesame+B.Aman & 500 & 0.11 & 1 \\
\hline 14 & Maize-B.Aman & 450 & 0.10 & 3 \\
\hline 15 & S.Potato-B.Aman & 440 & 0.10 & 2 \\
\hline 16 & Onion-B.Aman & 395 & 0.09 & 6 \\
\hline 17 & Sesame-B.Aman & 330 & 0.08 & 2 \\
\hline 18 & Garlic-B.Aman & 220 & 0.05 & 4 \\
\hline 19 & Muskmelon-B.Aman & 175 & 0.04 & 4 \\
\hline 20 & Blackgram-B.Aman & 170 & 0.04 & 3 \\
\hline 21 & Potato+Maize-B.Aman & 110 & 0.03 & 2 \\
\hline $22-24$ & Other three patterns (in Table 8) & 110 & 0.03 & - \\
\hline & Total deep-water rice & 70655 & 16.11 & \\
\hline
\end{tabular}

cultivated in the smallest area. Eight cropping patterns of lentil jointly cover more than onehalf of the total pulse area in the region (Tables 6 and 8). Grasspea holds the second position in pulse crop cultivation in Comilla region. There are five cropping patterns for grasspea which in-together occupy over one-fourth of total pulse crop cultivation area in the region. In the documentation of pulse cropping system it is observed that majority of pulse crop are is under deep-water rice ecosystem. Finally the aggregate area of the pulse cropping system stands for $1.93 \%$ of the NCA in Comilla region.

\section{Vegetables and spices crops}

Table 7 presents 58 cropping patterns arranged in descending order according to area coverage. Potato and other vegetables of Rabi, Kharif-I and Kharif-II; spices (chilli, onion, garlic, coriander) are included in this list. The most contributing cropping pattern is PotatoMaize-Fallow covering $1.61 \%$ of NCA which is distributed over only five upazilas. The second one is Vegetable-Vegetable-Vegetable covering $1.60 \%$ of NCA and it is the most available pattern recorded in 22 upazilas out of 33.

\section{Sporadic and distinct cropping patterns}

There are some cropping patterns which are extremely location-specific, however, with a large area coverage. These are Single $\mathrm{T}$. Aman (Table 2); Mustard-Aus-Fallow (Table 5) and Maize-Fallow-Fallow (Table 4). The single T. Aman is grown on 3,430 hectares in Chouddagram upazila of Comilla district. The area is situated on the foot hill border of India and the water holding capacity of its soil is low. Boro is not possible due the scarcity of irrigation water in dry season. Some nonrice crops viz maize might be grown after $\mathrm{T}$. Aman. Sesame might be suggested in Kharif-I season. Mustard-Aus-Fallow is limited to two upazilas viz Muradnagar upazila of Comilla district (1,800 ha) and Chandpur sadar upazila (100 ha). Maize-Fallow-Fallow is available in Daudkandi upazila (1,200 ha) and Titas (300 ha) of Comilla district. 
Table 5. Cropping patterns for oil-seed crops in Comilla region, 2014-15.

\begin{tabular}{|c|c|c|c|c|}
\hline & Cropping pattern & Area (ha) & $\%$ of NCA & Frequency (no. of upazila) \\
\hline 01 & Mustard-B.Aman & 9690 & 2.21 & 9 \\
\hline 02 & Mustard-Boro-Fallow & 3810 & 0.87 & 12 \\
\hline 03 & Mustard-Boro-T. Aman & 2100 & 0.48 & 6 \\
\hline 04 & Mustard-Aus-Fallow & 1900 & 0.43 & 2 \\
\hline 05 & Mustard-Boro-Aus-T. Aman & 1470 & 0.34 & 9 \\
\hline 06 & Mustard-Maize-T. Aman & 1030 & 0.23 & 2 \\
\hline 07 & Mustard-Jute-Fallow & 730 & 0.17 & 5 \\
\hline 08 & Soybean-Fallow-Fallow & 700 & 0.16 & 2 \\
\hline 09 & Soybean-B.Aman & 550 & 0.13 & 1 \\
\hline 10 & Mustard-Boro-B.Aman & 500 & 0.11 & 4 \\
\hline 11 & Mustard-Sesame+B.Aman & 500 & 0.11 & 1 \\
\hline 12 & Mustard-Fallow-T. Aman & 400 & 0.09 & 1 \\
\hline 13 & Soybean-Fallow-T. Aman & 400 & 0.09 & 1 \\
\hline 14 & Mustard-Boro-Aus & 330 & 0.08 & 2 \\
\hline 15 & Sesame-B.Aman & 330 & 0.08 & 2 \\
\hline 16 & Sesame-Fallow-T. Aman & 300 & 0.07 & 1 \\
\hline 17 & Mustard-Aus-T. Aman & 245 & 0.06 & 4 \\
\hline 18 & Lentil-Sesame-Fallow & 170 & 0.04 & 3 \\
\hline 19 & Groundnut- Aus-T. Aman & 160 & 0.04 & 2 \\
\hline 20 & Groundnut-Sesame-Fallow & 150 & 0.03 & 1 \\
\hline 21 & Soybean-Jute-Fallow & 130 & 0.03 & 1 \\
\hline 22 & Potato-Sesame-T. Aman & 125 & 0.03 & 4 \\
\hline \multirow[t]{2}{*}{$23-31$} & Other nine patterns (in Table 8) & 530 & 0.12 & - \\
\hline & Total oil-seed crops & 26250 & 6.03 & \\
\hline
\end{tabular}

Table 6. Cropping patterns for pulse crops in Comilla region, 2014-15.

\begin{tabular}{|c|c|c|c|c|}
\hline & Cropping pattern & Area (ha) & $\%$ of NCA & Frequency (no. of upazila) \\
\hline 01 & Lentil-B.Aman & 2970 & 0.68 & 10 \\
\hline 02 & Grasspea-B.Aman & 1785 & 0.41 & 9 \\
\hline 03 & Boro-Fallow-Blackgram & 880 & 0.20 & 2 \\
\hline 04 & Lentil-Jute-T. Aman & 500 & 0.11 & 1 \\
\hline 05 & Grasspea-Jute-T. Aman & 400 & 0.09 & 1 \\
\hline 06 & Lentil-Jute-Fallow & 360 & 0.08 & 3 \\
\hline 07 & Lentil-Jute-Fallow & 360 & 0.08 & 3 \\
\hline 08 & Fallow-Fallow-Blackgram & 350 & 0.08 & 5 \\
\hline 09 & Blackgram-B.Aman & 170 & 0.04 & 3 \\
\hline 10 & Lentil-Sesame-Fallow & 170 & 0.04 & 3 \\
\hline \multirow[t]{2}{*}{$11-22$} & Other 12 patterns (in Table 8) & 495 & 0.11 & - \\
\hline & Total pulse crops & 8440 & 1.93 & \\
\hline
\end{tabular}

\section{Rare cropping patterns}

In the present investigation, 44 cropping patterns have been identified as rare cropping patterns with a negligible area coverage with seldom existence (Table 8). These are location specific system and are limited in one or two and in some cases three upazilas of the region. Total area coverage of the 44 patterns is far less than $1 \%$ of NCA. Among these the highest area was allotted for Grasspea-JuteFallow, Groundnut-Aus-Fallow, MungbeanAus-T. Aman, Potato-Vegetab-T. Amanand Soybean-Aus-T. Aman (100 ha for each) and these are recoded dispersedly in Haimcharand Faridganj upazila of Chandpur district, Titas upazila of Comilla district and B. Baria sadar 
Table 7. Cropping patterns for vegetables and spices in Comilla region, 2014-15.

\begin{tabular}{|c|c|c|c|c|}
\hline & Cropping pattern & Area (ha) & $\%$ of NCA & Frequency (no. of upazila) \\
\hline 01 & Potato-Maize-Fallow & 7050 & 1.61 & 5 \\
\hline 02 & Vegetab-Vegetab-Vegetab & 7030 & 1.60 & 22 \\
\hline 03 & Vegetab-Vegetab-Fallow & 6840 & 1.56 & 16 \\
\hline 04 & Potato-Boro-Fallow & 4250 & 0.97 & 4 \\
\hline 05 & Potato-Jute-Fallow & 3870 & 0.88 & 11 \\
\hline 06 & Potato-Aus-T. Aman & 2500 & 0.57 & 8 \\
\hline 07 & Potato-Boro-T. Aman & 2120 & 0.48 & 9 \\
\hline 08 & Vegetab-Aus-T. Aman & 1775 & 0.40 & 7 \\
\hline 09 & Vegetab-Aus-Fallow & 1640 & 0.37 & 7 \\
\hline 10 & Boro-Vegetab(Float/Norm) & 1230 & 0.28 & 3 \\
\hline 11 & Vegetab-Fallow-Fallow & 1180 & 0.27 & 6 \\
\hline 12 & Vegetab-Fallow-T. Aman & 1160 & 0.26 & 6 \\
\hline 13 & Potato-Maize-T. Aman & 930 & 0.21 & 4 \\
\hline 14 & Maize-Vegetab-Fallow & 800 & 0.18 & 1 \\
\hline 15 & Potato+S.gourd-Aus-T. Aman & 740 & 0.17 & 3 \\
\hline 16 & Chilli-Jute-Fallow & 725 & 0.17 & 6 \\
\hline 17 & Chilli-Aus-T. Aman & 710 & 0.16 & 3 \\
\hline 18 & Coriander-Fallow-Fallow & 700 & 0.16 & 4 \\
\hline 19 & Potato-Boro-Aus-T. Aman & 630 & 0.14 & 4 \\
\hline 20 & Chilli-Fallow-Fallow & 600 & 0.14 & 3 \\
\hline 21 & Vegetab-Vegetab-T. Aman & 580 & 0.13 & 3 \\
\hline 22 & Potato-Sesbania & 550 & 0.13 & 2 \\
\hline 23 & Chilli-Fallow-T. Aman & 425 & 0.10 & 7 \\
\hline 24 & Onion-Jute-Fallow & 400 & 0.09 & 2 \\
\hline 25 & Garlic-Jute-Fallow & 390 & 0.09 & 2 \\
\hline 26 & Vegetab-Boro-Aus-T. Aman & 370 & 0.08 & 3 \\
\hline 27 & Vegetab-Jute-Fallow & 335 & 0.08 & 6 \\
\hline 28 & Vegetab-Jute-T. Aman & 310 & 0.07 & 5 \\
\hline 29 & Onion-Fallow-T. Aman & 305 & 0.07 & 2 \\
\hline 30 & Coriander-Fallow-T. Aman & 220 & 0.05 & 5 \\
\hline 31 & Chilli-Vegetab-Fallow & 220 & 0.05 & 5 \\
\hline 32 & Potato-S.gourd-Aus & 180 & 0.04 & 3 \\
\hline 33 & Garlic-Fallow-T. Aman & 155 & 0.04 & 2 \\
\hline 34 & Chilli-Jute-T. Aman & 150 & 0.03 & 1 \\
\hline 35 & Potato-Aus-Fallow & 120 & 0.03 & 3 \\
\hline 36 & Potato+Maize-B.Aman & 110 & 0.03 & 2 \\
\hline \multirow[t]{2}{*}{$37-58$} & Other 22 patterns (in Table 8) & 845 & 0.19 & - \\
\hline & Total for vegetables and spices & 52145 & 11.90 & \\
\hline
\end{tabular}

upazila. The smallest area was recorded for three cropping patterns whose coverage was five hectares for each (Table 8).

\section{Most dominant cropping pattern}

Single Boro was the most dominant cropping pattern in Comilla region. It covers $26.18 \%$ of NCA in the region and is available in 30 upazilas out of 33 (Table 9). The highest area 1,1650 ha under this cropping pattern was recorded in Nasirnagar upazila of B. Baria district, which represents $10.15 \%$ of the total Boro-Fallow-Fallow area of the region. In consideration of individual upazila Hajiganj upazila of Chandpur district has allocated the highest area and it is 75\% of its NCA for this pattern alone. This area covered by deepwater in wet season and is only cultivable in the dry season. Farmers are not interested to cultivate deepwater rice because of its low yield. If 
Table 8. Rare cropping patterns covering non-significant area in Comilla region, 2014-15.

\begin{tabular}{|c|c|c|c|c|c|}
\hline & Cropping pattern & Area (ha) & $\%$ of NCA & Frequency & Upazila \\
\hline 01 & Grasspea-Jute-Fallow & 100 & 0.02 & 1 & Haimchar \\
\hline 02 & Groundnut- Aus-Fallow & 100 & 0.02 & 1 & Titas \\
\hline 03 & Mungbean-Aus-T. Aman & 100 & 0.02 & 2 & Faridganj+Haimchar \\
\hline 04 & Potato-Vegetab-T. Aman & 100 & 0.02 & 1 & B.Baria sadar \\
\hline 05 & Soybean-Aus-T. Aman & 100 & 0.02 & 1 & Haimchar \\
\hline 06 & Onion-Sesame-Fallow & 90 & 0.02 & 2 & Bancharampur+Homna \\
\hline 07 & Chilli-Aus-Fallow & 80 & 0.02 & 1 & Homna \\
\hline 08 & Mustard-Jute-T. Aman & 80 & 0.02 & 1 & Brahmanpara \\
\hline 09 & Soybean-Jute-T. Aman & 70 & 0.02 & 1 & Faridganj \\
\hline 10 & Vegetab-Maize-Fallow & 70 & 0.02 & 1 & Faridganj \\
\hline 11 & Garlic-Fallow-Fallow & 60 & 0.01 & 1 & Bancharampur \\
\hline 12 & Lentil-Aus-T. Aman & 60 & 0.01 & 1 & Matlab North \\
\hline 13 & Coriander-Vegetab-Fallow & 55 & 0.01 & 3 & Burichang+Laksam+Monoharganj \\
\hline 14 & Mungbean-B.Aus+B.Aman & 50 & 0.01 & 1 & Matlab South \\
\hline 15 & Onion-Vegtab-Vegetab & 50 & 0.01 & 1 & Brahmanpara \\
\hline 16 & Potato-Fallow-T. Aman & 50 & 0.01 & 2 & Haimchar+Burichang \\
\hline 17 & Vegetab-Fallow-Blackgram & 50 & 0.01 & 2 & Comilla South+Nangolkot \\
\hline 18 & Onion-Aus-T. Aman & 40 & 0.01 & 3 & B.Baria sadar+Chandina+Debidwar \\
\hline 19 & Pea-B.Aman & 40 & 0.01 & 3 & Homna+Meghna+Muradnagar \\
\hline 20 & Groundnut-Fallow-Fallow & 35 & 0.01 & 3 & Bancharampur+Nasirnagar+Debidwar \\
\hline 21 & Potato-Jute-T. Aman & 30 & 0.01 & 1 & Brahmanpara \\
\hline 22 & Potato-Maize-Aus-Vegetab & 30 & 0.01 & 1 & Debidwar \\
\hline 23 & Sesame-Fallow-Blackgram & 30 & 0.01 & 1 & Homna \\
\hline 24 & S.Potato-Jute-Fallow & 30 & 0.01 & 1 & ComillaSouth \\
\hline 25 & Vegetab-Boro-T. Aman & 30 & 0.01 & 1 & Kachua \\
\hline 26 & Garlic-Vegetab-Vegetab & 25 & 0.01 & 2 & Brahmanpara+Debidwar \\
\hline 27 & Fallow-B.Aman & 20 & 0.00 & 1 & Laksam \\
\hline 28 & Lentil-Fallow-T. Aman & 20 & 0.00 & 1 & Chauddagram \\
\hline 29 & Lentil-Maize-T. Aman & 20 & 0.00 & 1 & Matlab North \\
\hline 30 & Muskmelon-F-T. Aman & 20 & 0.00 & 1 & Debidwar \\
\hline 31 & Potato-Boro-Aus & 20 & 0.00 & 1 & Brahmanpara \\
\hline 32 & Groundnut-Fallow-T. Aman & 15 & 0.00 & 2 & Chandina+Chouddagram \\
\hline 33 & Blackgram-Jute-T. Aman & 10 & 0.00 & 1 & B.Baria sadar \\
\hline 34 & Coriander-Jute-T. Aman & 10 & 0.00 & 1 & Kachua \\
\hline 35 & Garlic-Aus-Fallow & 10 & 0.00 & 1 & Debidwar \\
\hline 36 & Garlic-Aus-T. Aman & 10 & 0.00 & 1 & Chandina \\
\hline 37 & Garlic-Jute-T. Aman & 10 & 0.00 & 1 & Nasirnagar \\
\hline 38 & Grasspea-Fallow-Fallow & 10 & 0.00 & 1 & Titas \\
\hline 39 & Mustard-Fallow-Fallow & 10 & 0.00 & 1 & Monoharganj \\
\hline 40 & Onion-Jute-T. Aman & 10 & 0.00 & 1 & Nasirnagar \\
\hline 41 & Wheat-Vegetab-Vegetab & 10 & 0.00 & 1 & Homna \\
\hline 42 & Chilli-Vegetab-T. Aman & 5 & 0.00 & 1 & Monoharganj \\
\hline 43 & Mungbean-Jute-T. Aman & 5 & 0.00 & 1 & Debidwar \\
\hline \multirow[t]{2}{*}{44} & W.Melon-Fallow-T. Aman & 5 & 0.00 & 1 & Debidwar \\
\hline & Total & 1775 & 0.40 & & \\
\hline
\end{tabular}


Table 9. Distribution of the most dominant Boro-F-F cropping pattern in Comilla region, 2014-15.

\begin{tabular}{|c|c|c|c|c|}
\hline & Upazila & Area (ha) & $\%$ of upazila NCA & $\%$ of the pattern in region \\
\hline 01 & Nasirnagar & 11650 & 44.72 & 10.15 \\
\hline 02 & Nabinagar & 10600 & 40.15 & 9.24 \\
\hline 03 & Sarail & 9500 & 57.58 & 8.28 \\
\hline 04 & Hajiganj & 9000 & 75.00 & 7.84 \\
\hline 05 & Bijoynagar & 8500 & 58.22 & 7.41 \\
\hline 06 & Bancharampur & 7500 & 54.55 & 6.53 \\
\hline 07 & Dauadkandi & 7000 & 47.95 & 6.10 \\
\hline 08 & Monoharganj & 6250 & 60.10 & 5.45 \\
\hline 09 & B.Baria & 4800 & 31.79 & 4.18 \\
\hline 10 & Laksam & 4250 & 41.67 & 3.70 \\
\hline 11 & Titas & 4200 & 57.53 & 3.66 \\
\hline 12 & Kasba & 3500 & 22.95 & 3.05 \\
\hline 13 & Chandpur & 3000 & 25.86 & 2.61 \\
\hline 14 & Matlab sadar & 2900 & 31.87 & 2.53 \\
\hline 15 & Faridganj & 2800 & 23.93 & 2.44 \\
\hline 16 & Homna & 2500 & 25.38 & 2.18 \\
\hline 17 & Muradnagar & 2500 & 10.59 & 2.18 \\
\hline 18 & Meghna & 2100 & 29.58 & 1.83 \\
\hline 19 & Nangolkot & 1900 & 12.42 & 1.66 \\
\hline 20 & Brahmanpara & 1870 & 19.58 & 1.63 \\
\hline 21 & Akhaura & 1700 & 26.36 & 1.48 \\
\hline 22 & Sarail & 1700 & 15.96 & 1.48 \\
\hline 23 & Kachua & 1300 & 7.78 & 1.13 \\
\hline 24 & Matlab North & 900 & 6.16 & 0.78 \\
\hline 25 & Chandina & 760 & 6.23 & 0.66 \\
\hline 26 & Haimchar & 500 & 10.53 & 0.44 \\
\hline 27 & Comilla South & 500 & 2.96 & 0.44 \\
\hline 28 & Debidwar & 500 & 3.25 & 0.44 \\
\hline 29 & Ashuganj & 300 & 5.88 & 0.26 \\
\hline \multirow[t]{2}{*}{30} & Chouddagram & 300 & 1.63 & 0.26 \\
\hline & Comilla region & 114780 & 26.18 & 100.00 \\
\hline
\end{tabular}

modern varieties of deepwater rice can be made available, hopefully farmers will cultivate the land in wet season also. Debidwar, Ashuganj and Chouddagram upazila had a negligible area coverage for this pattern. In the countrywide compilation of data, it was observed that the single Boro was the $2^{\text {nd }}$ dominant cropping pattern in Bangladesh covering 1.14 million ha (13\% of NCA in the country) with its distribution in 342 upazilas of 59 districts (Nasim et al., 2017).

\section{Second dominant cropping pattern}

The second dominant cropping pattern in Comilla region is Boro-Fallow-T. Aman. It belongs to $19.93 \%$ of $\mathrm{NCA}$ of the region and spread out over 25 upazilas (Table 10). Chouddagram upazila of Comilla district holds the highest area (10,900 ha) under this double rice cropping system. This upazila contributes $12.47 \%$ share of Boro-Fallow-T. Aman cropping area in the region. Faridganj upazila of Chandpur district stands in the sixth position, however, this upazila has allocated $62.39 \%$ surface, the biggest share, of its NCA. In some portion of the double rice area some short duration Rabi crops can be grown before Boro transplanting if appropriate varieties and other related technologies are made available (FAO, 1988). In the country-wide compilation of data it was observed that Boro-F-T. Aman was the most dominant cropping pattern in 
Table 10. Distribution of the $2^{\text {nd }}$ dominant Boro-F-T. Aman cropping pattern in Comilla region, $2014-15$.

\begin{tabular}{|c|c|c|c|c|}
\hline & Upazila & Area (ha) & $\%$ of upazila NCA & $\%$ of the pattern in region \\
\hline 01 & Chouddagram & 10900 & 59.08 & 12.47 \\
\hline 02 & Comilla sadar South & 8000 & 47.34 & 9.15 \\
\hline 03 & B.Baria & 7800 & 51.66 & 8.92 \\
\hline 04 & Faridganj & 7300 & 62.39 & 8.35 \\
\hline 05 & Kasba & 6700 & 43.93 & 7.67 \\
\hline 06 & Matlab North & 5000 & 34.25 & 5.72 \\
\hline 07 & Bijoynagar & 4700 & 32.19 & 5.38 \\
\hline 08 & Burichang & 4600 & 40.00 & 5.26 \\
\hline 09 & Sarail & 4400 & 26.67 & 5.03 \\
\hline 10 & Comilla Adorsho sadar & 4400 & 59.86 & 5.03 \\
\hline 11 & Nangolkot & 4400 & 28.76 & 5.03 \\
\hline 12 & Akhaura & 3500 & 54.26 & 4.00 \\
\hline 13 & Nabinagar & 2800 & 10.61 & 3.20 \\
\hline 14 & Ashuganj & 2400 & 47.06 & 2.75 \\
\hline 15 & Chandpur & 2300 & 19.83 & 2.63 \\
\hline 16 & Brahmanpara & 2000 & 20.94 & 2.29 \\
\hline 17 & Debidwar & 1600 & 10.39 & 1.83 \\
\hline 18 & Nasirnagar & 1350 & 5.18 & 1.54 \\
\hline 19 & Barura & 1110 & 6.81 & 1.27 \\
\hline 20 & Muradnagar & 900 & 3.81 & 1.03 \\
\hline 21 & Chandina & 500 & 4.10 & 0.57 \\
\hline 22 & Bancharampur & 360 & 2.62 & 0.41 \\
\hline 23 & Laksam & 300 & 2.94 & 0.34 \\
\hline 24 & Haimchar & 50 & 1.05 & 0.06 \\
\hline \multirow[t]{2}{*}{25} & Matlab South & 40 & 0.44 & 0.05 \\
\hline & Comilla region & 87410 & 19.93 & 100.00 \\
\hline
\end{tabular}

Table 11. Distribution of the $3^{\text {rd }}$ dominant Boro-Aus-T. Aman cropping pattern in Comilla region, 2014-15.

\begin{tabular}{|c|c|c|c|c|}
\hline & Upazila & Area (ha) & $\%$ of upazila NCA & $\%$ of the pattern in region \\
\hline 01 & Barura & 11200 & 68.71 & 17.28 \\
\hline 02 & Debidwar & 7500 & 48.70 & 11.57 \\
\hline 03 & Comilla sadar South & 5700 & 33.73 & 8.79 \\
\hline 04 & Chandina & 5000 & 40.98 & 7.71 \\
\hline 05 & Nangolkot & 4900 & 32.03 & 7.56 \\
\hline 06 & Laksam & 4700 & 46.08 & 7.25 \\
\hline 07 & Kachua & 3900 & 23.35 & 6.02 \\
\hline 08 & Burichang & 3700 & 32.17 & 5.71 \\
\hline 09 & Matlab North & 3300 & 22.60 & 5.09 \\
\hline 10 & Brahmanpara & 3160 & 33.09 & 4.87 \\
\hline 11 & Muradnagar & 2000 & 8.47 & 3.08 \\
\hline 12 & Kasba & 1700 & 11.15 & 2.62 \\
\hline 13 & Comilla Adarsha sadar & 1500 & 20.41 & 2.31 \\
\hline 14 & Chouddagram & 1300 & 7.05 & 2.01 \\
\hline 15 & Saharasti & 1200 & 11.27 & 1.85 \\
\hline 16 & Ashuganj & 900 & 17.65 & 1.39 \\
\hline 17 & Nabinagar & 900 & 3.41 & 1.39 \\
\hline 18 & B.Baria & 800 & 5.30 & 1.23 \\
\hline 19 & Haimchar & 470 & 9.89 & 0.72 \\
\hline 20 & Chandpur sadar & 400 & 3.45 & 0.62 \\
\hline 21 & Bijoynagar & 200 & 1.37 & 0.31 \\
\hline 22 & Nasirnagar & 200 & 0.77 & 0.31 \\
\hline 23 & Sarail & 150 & 0.91 & 0.23 \\
\hline 24 & Akhaura & 20 & 0.31 & 0.03 \\
\hline 25 & Monoharganj & 20 & 0.19 & 0.03 \\
\hline \multirow[t]{2}{*}{26} & Matlab South & 10 & 0.11 & 0.02 \\
\hline & Comilla region & 64830 & 14.78 & 100.00 \\
\hline
\end{tabular}

102 Saha et al 
Table 12. Distribution of the $4^{\text {th }}$ dominant Boro-B. Aman cropping pattern in Comilla region, 2014-15.

\begin{tabular}{llcrc}
\hline & Upazila & Area (ha) & \% of upazila NCA & $\%$ of the pattern in region \\
\hline 01 & Shaharasti & 6800 & 63.85 & 17.73 \\
02 & Kachua & 6700 & 40.12 & 17.47 \\
03 & Nabinagar & 5700 & 21.59 & 14.86 \\
04 & Muradnagar & 4000 & 16.95 & 10.43 \\
05 & Monoharganj & 3850 & 37.02 & 10.04 \\
06 & Homna & 2900 & 29.44 & 7.56 \\
07 & Nasirnagar & 2200 & 8.45 & 5.74 \\
08 & Bancharampur & 1600 & 11.64 & 4.17 \\
09 & Meghna & 1200 & 16.90 & 3.13 \\
10 & Chandina & 750 & 6.15 & 1.96 \\
11 & Nangolkot & 650 & 4.25 & 1.69 \\
12 & Debidwar & 550 & 3.57 & 1.43 \\
13 & Laksam & 500 & 4.90 & 1.30 \\
14 & Sarail & 350 & 2.12 & 0.91 \\
15 & Brahmanpara & 330 & 3.46 & 0.86 \\
16 & Hajiganj & 100 & 0.83 & 0.26 \\
17 & Barura & 100 & 0.61 & 0.26 \\
18 & Chandpur sadar & 50 & 0.43 & 0.13 \\
19 & Bijoynagar & 30 & 0.21 & 0.08 \\
\hline & Comilla region & 8.75 & 100.00 \\
\hline
\end{tabular}

Bangladesh covering 2.31 million ha (27\% of NCA in the country) with its distribution in 426 upazilas of 63 districts (Nasim et al., 2017).

\section{Third dominant cropping pattern}

Triple rice cropping system, Boro-Aus-T. Aman cropping pattern holds the third largest area coverage 64,830 hectares in Comilla region. This area is an equivalent to $14.78 \%$ of NCA in the region. This three-rice pattern is widely distributed over 26 upazilas. Barura upazila of Comilla district has the highest area coverage of 11,200 ha for three-rice system which stands for $17.28 \%$ of the total area under this pattern in the region (Table 11). Debidwar upazila of the same district ranks in second position for three-rice $(7,500 \mathrm{ha})$ which represents $48.70 \%$ of its NCA and this area is $11.57 \%$ of the total area for this particular pattern in the region. Though continuous rice cropping is not suggested by the researchers and extension personnel, however, this type of land is not suitable for cultivation of non-rice crops. In this context, to maintain the fertility of the soils and for better crop production suggestions should be recommended for proper dose of chemical fertilizer, application of organic manure and retention of sufficient rice straw in the field.
Fourth dominant cropping pattern

Fourth dominant cropping pattern Boro-B. Aman has occupied 38,360 hectares representing $8.75 \%$ share of NCA in Comilla region (Table 12). This pattern is distributed over 19 upazilas where Shaharasti upazila of Chandpur district ranked in top position. This upazila has 6,800 ha area of Boro-B.Aman which alone represents $63.85 \%$ of upazila NCA. In consideration of the whole this area is equivalent to $17.73 \%$ of total area for this particular pattern in the region. Kachua upazila of the same district ranks in second position with 6,700 ha area for this pattern. In the same way this upazila has allotted the second biggest share $(40.12 \%)$ of its NCA. The area normally belongs to medium high land-II and medium low land. Therefore, in wet season there is no scope of T. Aman cultivation. In some portion of this area mixed B. Aus+B.Aman cropping system might be introduced to boost up the productivity.

\section{Fifth dominant cropping pattern}

Fifth dominant cropping pattern Mustard-B. Aman had been covering 9,690 hectares representing $2.21 \%$ share of NCA in Comilla region (Table 13). This pattern is distributed over only nine upazilas where Nasirnagar 
Table 13. Distribution of the $5^{\text {th }}$ dominant Mustard-B.Aman cropping pattern in Comilla region, $2014-15$.

\begin{tabular}{llccr}
\hline & Upazila & Area (ha) & \%of upazila NCA & \% of the pattern in region \\
\hline 01 & Nasirnagar & 4880 & 18.73 & 50.36 \\
02 & Muradnagar & 2600 & 10.95 & 26.83 \\
03 & Bancharampur & 600 & 4.36 & 6.19 \\
04 & Nabinagar & 440 & 1.67 & 4.54 \\
05 & Kasba & 400 & 2.60 & 4.13 \\
06 & Meghna & 270 & 3.80 & 2.79 \\
07 & Nangolkot & 250 & 1.63 & 2.58 \\
08 & Brahmanpara & 220 & 2.32 & 2.27 \\
09 & Shaharasti & 30 & 0.28 & 0.31 \\
\hline & Comilla region & 9690 & 2.21 & 100.00 \\
\hline
\end{tabular}

Table 14. Crop diversity and cropping intensity in Comilla region, 2014-15.

\begin{tabular}{|c|c|c|c|c|c|c|}
\hline & Upazila & $\begin{array}{c}\text { No. of identified } \\
\text { pattern }\end{array}$ & No. of crop & $\begin{array}{l}\text { Diversity index for } \\
\text { cropping pattern }\end{array}$ & $\begin{array}{l}\text { Crop diversity } \\
\text { index (CDI) }\end{array}$ & C.I. (\%) \\
\hline 01 & Akhaura & 07 & 07 & 0.624 & 0.776 & 174 \\
\hline 02 & Ashuganj & 07 & 08 & 0.705 & 0.872 & 215 \\
\hline 03 & B.Baria & 15 & 14 & 0.627 & 0.772 & 181 \\
\hline 04 & Bijoynagar & 11 & 07 & 0.559 & 0.737 & 144 \\
\hline 05 & Bancharampur & 24 & 20 & 0.682 & 0.829 & 141 \\
\hline 06 & Kasba & 12 & 11 & 0.739 & 0.872 & 195 \\
\hline 07 & Nabinagar & 16 & 15 & 0.774 & 0.898 & 170 \\
\hline 08 & Nasirnagar & 24 & 20 & 0.751 & 0.877 & 156 \\
\hline 09 & Sarail & 13 & 12 & 0.594 & 0.774 & 146 \\
\hline 10 & Chandpur & 20 & 20 & 0.865 & 0.925 & 166 \\
\hline 11 & Faridganj & 14 & 10 & 0.566 & 0.749 & 180 \\
\hline 12 & Haimchar & 24 & 17 & 0.930 & 0.964 & 208 \\
\hline 13 & Hajiganj & 13 & 11 & 0.433 & 0.637 & 126 \\
\hline 14 & Kachua & 16 & 08 & 0.761 & 0.891 & 221 \\
\hline 15 & Matlab.N & 20 & 17 & 0.822 & 0.925 & 236 \\
\hline 16 & Matlab.S & 17 & 14 & 0.801 & 0.894 & 168 \\
\hline 17 & Shaharasti & 11 & 09 & 0.558 & 0.773 & 197 \\
\hline 18 & Barura & 15 & 13 & 0.522 & 0.832 & 292 \\
\hline 19 & Brahmanpara & 20 & 17 & 0.800 & 0.903 & 221 \\
\hline 20 & Burichang & 13 & 15 & 0.724 & 0.889 & 244 \\
\hline 21 & Chouddagram & 18 & 17 & 0.605 & 0.785 & 188 \\
\hline 22 & Chandina & 33 & 20 & 0.806 & 0.911 & 250 \\
\hline 23 & Com.Adarsha & 07 & 08 & 0.590 & 0.481 & 129 \\
\hline 24 & Com.South & 19 & 12 & 0.659 & 0.862 & 240 \\
\hline 25 & Daudkandi & 12 & 07 & 0.668 & 0.791 & 144 \\
\hline 26 & Debidwar & 36 & 21 & 0.739 & 0.891 & 265 \\
\hline 27 & Homna & 27 & 16 & 0.832 & 0.891 & 176 \\
\hline 28 & Nangolkot & 16 & 13 & 0.769 & 0.900 & 231 \\
\hline 29 & Laksam & 14 & 10 & 0.612 & 0.806 & 205 \\
\hline 30 & Meghna & 15 & 13 & 0.828 & 0.911 & 170 \\
\hline 31 & Monoharganj & 13 & 13 & 0.504 & 0.677 & 140 \\
\hline 32 & Muradnagar & 35 & 20 & 0.909 & 0.956 & 209 \\
\hline \multirow[t]{2}{*}{33} & Titas & 20 & 13 & 0.656 & 0.795 & 132 \\
\hline & Comilla region & 146 & 33 & 0.859 & 0.935 & 192 \\
\hline
\end{tabular}

104 Saha et al 
upazila of B.Baria district ranked in top position. This upazila had 4,880 ha area for Mustard-B.Aman pattern which alone represented $50.36 \%$ of the total area for this pattern in the region. Muradnagar upazila of Comilla district had the $2^{\text {nd }}$ largest area 2,600 ha for this cropping. These two upazilas had contributed more than three-fourths share of the total Mustard-B. Aman area in the region. In this land type irrigation water might be less available. Boro cultivation is not possible in the dry season. In this situation other high yielding non-rice crop e.g. maize and mixed cropping of lentil+mustard might be suggested.

\section{Crop diversity and cropping intensity}

Higher number of available crops under cultivation in an area dictates its higher diversity. Number of cropping patterns is also a gross indicator of crop diversity. A total of 146 cropping patterns were identified in the whole area of Comilla region under this investigation. The highest number of cropping patterns was identified 36 in Debidwar upazila of Comilla district (Table 14). The lowest number of cropping patterns was identified seven in Akhura and Ashuganj upazila of B.Baria and Adarsha upazila of Comilla district followed by 11 in Shaharasti upazila of Chandpur and Bijoynagar upazila of B.Baria district. The higher number of cropping patterns is generally related to higher level of diversity indices for cropping pattern. The upazilas having lower number of cropping patterns were normally related to water logging. The lowest diversity index for cropping pattern was recorded 0.433 in Hajiganj upazila of Chandpur district followed by 0.504 in Monoharganj of Comilla district. In a study Shahidullah et al. (2006) also found lowest values for all the diversity and intensity parameters in water stagnant area of greater Noakhali. The highest value of diversity index for cropping pattern was found 0.930 in Haimchar upazila of Chandpur district and that was followed by 0.909 in Muradnagar upazila of Comilla district. The lowest crop diversity index (CDI) was reported 0.481 in Comilla Adrasha upazila followed by 0.637 in Hajiganj upazila of Chandpur district. The highest value of CDI was observed 0.964 in Haimchar upazila of Chandpur followed by 0.956 in Muradnagar upazila of Comilla district. The range of cropping intensity (CI) value was recorded 126-292\%. The maximum value was for Barura upazila of Comilla district and minimum for Hajiganj upazila of Chandpur district. As a whole the CDI for Comilla region was calculated 0.935 and the average cropping intensity at regional level was $192 \%$. In a simultaneous study, the investigators identified 316 cropping patterns for whole Bangladesh; where the CDI value was 0.952 at national level and the national average of cropping intensity was 200\% (Nasim et al., 2017). Diversification of crops helps risk reduction as diversification allows a producer to balance low price in one or two crops with reasonable prices in other (Blade and Slinkard, 2002). The farmers of Kerala diversified their cropping pattern to minimize risk from due to crop failures and price fluctuations (Mahesh, 1999).

\section{CONCLUSION}

The cropping intensity of the Comilla region was little bit lower than the national average. Single Boro, Boro-Fallow-T. Aman, Boro-T. Aus-T. Aman, Boro-B.Aman, Mustard-B. Aman were the major cropping patterns in the region. Exclusive rice area is about nine folds of exclusive non-rice area. The non-rice based cropping patterns were either few or area under those cropping patterns were much lower, which are the challenges to food and nutritional security for the people of the Comilla region. Based on the findings of the study, the following recommendations were made.

- Initiative to be taken to increase productivity of exclusive rice based cropping pattern.

- The cropping patterns with minor area coverage but wider existence might be expanded in the same upazilas or other upazilas of the region.

- In the single Boro area suitable vegetables might be grown on floating bed system in wet season. 
- The upazilas having unique or exceptional cropping patterns with large area coverage might be studied in-depth to extrapolate to similar environments.

\section{REFERENCES}

Agrawal, D J and A H Kassam. 1976. The importance of multiple cropping in increasing world food supplies. A special publication No. 27, American Society of Agronomy, Madison, Wisconsin. pp. 2-3.

Blade, S F and A E Slinkard 2002. New Crop Development: The Canadian Experience. In: Trends in New Crops and New Uses. J Janick and A Whipkey (Editors). ASHS Press, Alexandria.

FAO, 1988. Land Resources Appraisal of Bangladesh for Agricultural Development- Report 2: Agroecological regions of Bangladesh. Food and Agriculture Organization of the United Nations, Rome, Italy, 570p.

Gadge, S S. 2003. Influence of changes in cropping pattern on farmers' economic status. Indian J. Ext. Edu. 39(1\&2): 99-101.

Jackson, B R, A Yantasast, C Prechachat, M A Chowdhury and S M H Zaman. 1972. Breeding rice for deep-water areas. Pages 517-528 In: International Rice Research Institute, Rice Breeding, Los Baños, Philippines.
Kshirsagar, K G, S Pandey and M R Bellon. 1997. Farmers' perception, varietal characteristics and technology adoption: the case of rainfed village in eastern India. Discussion paper 5/97. Social Sciences Division, International Rice Research Institute. Los Baňos, Laguna, Philippines.

Mahesh, R. 1999. Causes and consequences of change in cropping pattern: A location specific study. Discussion Paper No. 11, Kerala Research Programme on Local Level Development, Centre for Development Studies, Thiruvananthapura.

Nasim, M, S M Shahidullah, A Saha, M A Muttaleb, T L Aditya, M A Ali and M S Kabir. 2017. Distribution of Crops and Cropping Patterns in Bangladesh. Bangladesh Rice J. 21(2): 1-55.

Neena, D. 1998. Interstate variation in cropping pattern in India. Indian J. Regi. Sci. 30(2): 57-69.

Rashid, M H, A H Khan and M M Alam. 2005. Cropping systems dynamics in greater Khustia. J. Bangladesh Agril. Univ. 3(2): 213-238.

Shahidullah, S M, M S A Talukder, M S Kabir, A H Khan and N E Elahi. 2006. Cropping patterns in the South East Coastal Region of Bangladesh. J. Agric. Rural Dev. 4(1\&2): 53-60.

Shriar, A J. 2000. Agricultural intensity and its measurement in frontier regions.Agroforestry Systems.49(3): 301-318. 
Appendix 1. List of cropping patterns in Comilla region, 2014-15.

\begin{tabular}{|c|c|c|c|c|c|}
\hline & Cropping pattern & Area(ha) & & Cropping pattern & Area(ha) \\
\hline 001 & Boro-Fallow-Fallow & 114780 & 052 & Vegetab-Vegetab-T. Aman & 580 \\
\hline 002 & Boro-Fallow-T. Aman & 87410 & 053 & Potato-Sesbania & 550 \\
\hline 003 & Boro-Aus-T. Aman & 64830 & 054 & Soybean-B.Aman & 550 \\
\hline 004 & Boro-B.Aman & 38360 & 055 & S.Potato-Fallow-T. Aman & 540 \\
\hline 005 & Mustard-B.Aman & 9690 & 056 & Lentil-Jute-T. Aman & 500 \\
\hline 006 & Potato-Maize-Fallow & 7050 & 057 & Mustard-Boro-B.Aman & 500 \\
\hline 007 & Vegetab-Vegetab-Vegetab & 7030 & 058 & Mustard-Sesame+B.Aman & 500 \\
\hline 008 & Vegetab-Vegetab-Fallow & 6840 & 059 & Maize-B.Aman & 450 \\
\hline 009 & Boro-Aus-Fallow & 4670 & 060 & S.Potato-B.Aman & 440 \\
\hline 010 & Potato-Boro-Fallow & 4250 & 061 & Chilli-Fallow-T. Aman & 425 \\
\hline 011 & Fallow-Aus-T. Aman & 4160 & 062 & Wheat-Fallow-T. Aman & 405 \\
\hline 012 & Potato-Jute-Fallow & 3870 & 063 & Grasspea-Jute-T. Aman & 400 \\
\hline 013 & Chilli-B.Aman & 3820 & 064 & Mustard-Fallow-T. Aman & 400 \\
\hline 014 & Mustard-Boro-Fallow & 3810 & 065 & Onion-Jute-Fallow & 400 \\
\hline 015 & Potato-B.Aman & 3720 & 066 & Soybean-Fallow-T. Aman & 400 \\
\hline 016 & Fallow-Fallow-T. Aman & 3430 & 067 & Onion-B.Aman & 395 \\
\hline 017 & Boro-Sesbania-T. Aman & 3000 & 068 & Garlic-Jute-Fallow & 390 \\
\hline 018 & Lentil-B.Aman & 2970 & 069 & Vegetab-Boro-Aus-T. Aman & 370 \\
\hline 019 & Potato-Aus-T. Aman & 2500 & 070 & Lentil-Jute-Fallow & 360 \\
\hline 020 & Vegetab-B.Aman & 2480 & 071 & Fallow-Fallow-Blackgram & 350 \\
\hline 021 & Wheat-B.Aman & 2140 & 072 & Vegetab-Jute-Fallow & 335 \\
\hline 022 & Potato-Boro-T. Aman & 2120 & 073 & Mustard-Boro-Aus & 330 \\
\hline 023 & Mustard-Boro-T. Aman & 2100 & 074 & Sesame-B.Aman & 330 \\
\hline 024 & Boro-Sesbania-Fallow & 1910 & 075 & S.Potato-Vegetab-Fallow & 330 \\
\hline 025 & Mustard-Aus-Fallow & 1900 & 076 & Vegetab-Jute-T. Aman & 310 \\
\hline 026 & Grasspea-B.Aman & 1785 & 077 & Wheat-Jute-T. Aman & 310 \\
\hline 027 & Vegetab-Aus-T. Aman & 1775 & 078 & Onion-Fallow-T. Aman & 305 \\
\hline 028 & Vegetab-Aus-Fallow & 1640 & 079 & Sesame-Fallow-T. Aman & 300 \\
\hline 029 & Maize-Fallow-Fallow & 1500 & 080 & Wheat-Aus-Fallow & 300 \\
\hline 030 & Mustard-Boro-Aus-T. Aman & 1470 & 081 & Wheat-Aus-T. Aman & 250 \\
\hline 031 & Boro-Vegetab(Float/Norm) & 1230 & 082 & Mustard-Aus-T. Aman & 245 \\
\hline 032 & Vegetab-Fallow-Fallow & 1180 & 083 & Chilli-Vegetab-Fallow & 220 \\
\hline 033 & Vegetab-Fallow-T. Aman & 1160 & 084 & Coriander-Fallow-T. Aman & 220 \\
\hline 034 & S.Potato-Fallow-Fallow & 1060 & 085 & Garlic-B.Aman & 220 \\
\hline 035 & Mustard-Maize-T. Aman & 1030 & 086 & Maize-Jute-Fallow & 190 \\
\hline 036 & Fallow-Sesame+B.Aman & 950 & 087 & Boro-Jute-T. Aman & 180 \\
\hline 037 & Potato-Maize-T. Aman & 930 & 088 & Potato-S.gourd-Aus & 180 \\
\hline 038 & Boro-Fallow-Blackgram & 880 & 089 & Muskmelon-B.Aman & 175 \\
\hline 039 & Maize-Aus-Fallow & 800 & 090 & Blackgram-B.Aman & 170 \\
\hline 040 & Maize-Vegetab-Fallow & 800 & 091 & Lentil-Sesame-Fallow & 170 \\
\hline 041 & Coriander-B.Aman & 790 & 092 & Groundnut- Aus-T. Aman & 160 \\
\hline 042 & Wheat-Jute-Fallow & 780 & 093 & Garlic-Fallow-T. Aman & 155 \\
\hline 043 & Potato+S.gourd-Aus-T. Aman & 740 & 094 & Chilli-Jute-T. Aman & 150 \\
\hline 044 & Mustard-Jute-Fallow & 730 & 095 & Groundnut-Sesame-Fallow & 150 \\
\hline 045 & Chilli-Jute-Fallow & 725 & 096 & Maize-Aus-T. Aman & 150 \\
\hline 046 & Chilli-Aus-T. Aman & 710 & 097 & Maize-Fallow-T. Aman & 140 \\
\hline 047 & Coriander-Fallow-Fallow & 700 & 098 & S.Potato-Jute-T. Aman & 140 \\
\hline 048 & Fallow-Jute-T. Aman & 700 & 099 & Soybean-Jute-Fallow & 130 \\
\hline 049 & Soybean-Fallow-Fallow & 700 & 100 & Potato-Sesame-T. Aman & 125 \\
\hline 050 & Potato-Boro-Aus-T. Aman & 630 & 101 & Potato-Aus-Fallow & 120 \\
\hline \multirow[t]{2}{*}{051} & Chilli-Fallow-Fallow & 600 & 102 & Potato+Maize-B.Aman & 110 \\
\hline & & & $103-146$ & Other 44 patterns (Table 8) & 1775 \\
\hline
\end{tabular}


